UDC 539.3

\title{
NONLINEAR PROBLEM OF STRUCTURAL DEFORMATION IN INTERACTION WITH ELASTOPLASTIC MEDIUM
}

\author{
I.I. Solodei, \\ DSc, Department of Structural mechanics \\ E.Yu. Petrenko, \\ $\mathrm{PhD}$, Department of Geotechnics \\ Gh.A. Zatyliuk, \\ Postgraduate student, Department of Structural mechanics \\ Kyiv National University of Construction and Architecture
}

DOI: $10.32347 / 2410-2547.2020 .105 .48-63$

\begin{abstract}
On the basis of modern numerical implementations of the finite element method the article presents the theoretical foundations of the analysis of deformation processes of machines and structures in their contact interaction with the elastic-plastic nonlinear soil medium within the three-dimensional spatial problem taking into account the previous stress state and load history. The methodology of construction of computational models of joint deformation and mutual influence of rigid structures and essentially plastic external medium is developed, new special heterogeneous finite elements of SAFEM of general form with variable geometrical and physicalmechanical parameters and arbitrary boundary conditions for approximation of arrays of hardly connected reinforced soils are developed.
\end{abstract}

Keywords: elastic-plastic medium, reinforced soils model, semi-analytical finite element method, moment scheme of finite element.

Introduction. Development of new and improvement of existing production technologies, application of new materials, effective constructive schemes is explained by constant complication of operating conditions. Acute shortage of territories, especially in large cities with dense buildings and limited land space, solving the transport collapse problem due to underground transport, laying pipelines and construction of ground and underground tanks for storage of fuel, water, chemical and food industries components, underground protective structures for military purposes - a small list of challenges that practicing engineers and scientists face today and encourage the continuous improvement of tools for comprehensive analysis of the model behavior that describe the interaction of structures with the environment.

The use of numerical methods in the calculation of machines and structures, taking into account their interaction with the elastic-plastic medium is largely determined by the complexity or even impossibility of analytical calculation due to the complexity of structural schemes, heterogeneity of material features, uneven soil layers, implementation of step-by-step work execution technologies and so on. The development of computer technologies has opened wide opportunities and encouraged researchers to use more complex models, the construction of which is accompanied by various issues: the choice of boundary conditions, load schemes, soil base models, taking into account the history of 
the structure final state. Therefore, the development on the basis of modern numerical implementations of the finite element method of new effective methods of computational mechanics for the analysis of nonlinear processes of deformation of structures and buildings in their contact with the elastic-plastic medium is certainly an actual problem of structural mechanics.

Compatible calculations of structures and nonlinear basis, which are described by modern mechanical and soil models in one problem is a significant technical problem. And neither the existing "problem-oriented" software packages, nor the "universal" ones - do not fully contain such models. In designing practice, the simplest Mohr-Coulomb Soil Model is often used for engineering calculations. The model is a logical continuation of the linearelastic model and is based on the Hooke's Law and the Coulomb's strength condition. Despite the model defects (ignoring the nonlinear dependences between deformations and stresses, constant modulus of deformation), it has a number of significant advantages (traditional parameters, the definition of which is clearly regulated by the norms) and continues to interest domestic and foreign scientists, researches on its improvement continue [31,1]. The achievements of modern soil mechanics are a large number of mathematical soil models: Hardening Soil Model and its derivatives (Hardening Soil Smallstrain), Soft Soil and its derivatives, Cam-Clay etc. Noteworthy are the works that compare different models [11,4], outline the possible limits of their use [12] and describe the application experience [21]. The Hardening Soil model is attracting more and more attention, which takes into account the soil hardening upon increasing stress levels. The biggest problems when using the model arise due to the large number of parameters, the definition of which is not regulated by the norms. Early publications contained a number of inaccuracies and errors, although they made an invaluable contribution to the model expansion, and recent publications have clarified a number of problematic issues [12]. Research on improving the model continues $[20,8]$.

The tasks solution is possible only within the framework of numerical methods, the most common of which is the finite element method (FEM) [24]. The construction of the calculated finite element model raises many complex questions that require additional detailed study. In addition, the compliance with the state building norms and regulations is an important factor for further practical use.

The combination of the latest achievements in the field of structural mechanics and soil mechanics is a promising direction for the development of effective approaches for building discrete models of spatial systems "structurenonlinear base" for solving applied problems.

1. Problem statement. Let's consider in some arbitrary coordinate system $Z^{i^{\prime}}$ spatial rotation bodies or prismatic bodies formed by the motion of some generating surface along a closed or open arbitrary guide without breaks and which are under the action of nonstationary load, in the time interval $T \in\left[t_{0}, t_{1}\right]$. 
The coordinate system $Z^{i^{\prime}}$ will be further called basic and used to describe the geometric and mechanical characteristics, initial and ultimate kinematic conditions, external loads. To represent the stress-strain state of the body, we introduce the local curvilinear coordinate system $x^{i}$, which is related to the body geometry. The coordinate lines $x^{1}$ and $x^{2}$ are placed in the generating surface area, and $x^{3}$ is oriented along the guide.

It is considered that at any point of the body there is a clear relationship between the basic and local coordinate systems, which is determined by the forward and inverse tensors of the coordinate transformation:

$$
z_{, j}^{i^{\prime}}=\frac{\partial Z^{i^{\prime}}}{\partial x^{j}}, x_{, j^{\prime}}^{i}=\frac{\partial x^{i}}{\partial Z^{j^{\prime}}} .
$$

Hereinafter, the indices denoted by Latin letters take the values 1, 2, 3, and by Greek - 1, 2, comma before the index shows the operation of differentiation.

The covariant components of the metric tensor of the local coordinate system can be represented through the covariant components of the basic system:

$$
g_{i j}=z_{, i}^{m^{\prime}} z_{, j}^{n^{\prime}} g_{m^{\prime} n^{\prime}} .
$$

The contravariant components are located under known covariants:

$$
g^{i j}=\frac{\mathrm{A}\left(g_{i j}\right)}{g},
$$

where $\mathrm{A}\left(g_{i j}\right)$ is the algebraic addition to the element $g_{i j}, g=\operatorname{det}\left[g_{i j}\right]$ is the matrix determinant.

Geometric Cauchy relationships in curvilinear coordinate systems. In the general case, the strain tensor components in the local coordinate system are determined by the ratio:

$$
\varepsilon_{i j}=\frac{1}{2}\left(u_{i, j}+u_{j, i}\right)-u_{k} \Gamma_{i j}^{k},
$$

where $u_{i, j}=\frac{\partial u_{i}}{\partial x^{j}}, \Gamma_{i j}^{k}$ are the Christoffel symbols of the second kind, $u_{i}$ is the movement in the local coordinate system.

For convenience, let's present the movements and the Christoffel symbols by their values in the basic coordinate system:

$$
\begin{gathered}
u_{k}=z_{, k}^{m^{\prime}} u_{m^{\prime}}, \\
\Gamma_{i j}^{k}=x_{r^{\prime}}^{k} z_{, i}^{m^{\prime}}\left(z_{, j}^{n^{\prime}} \Gamma_{m^{\prime} n^{\prime}}^{r^{\prime}}+\frac{\partial z_{, j}^{r^{\prime}}}{\partial z^{m^{\prime}}}\right),
\end{gathered}
$$

where $z_{, k}^{s^{\prime}} x_{, r^{\prime}}^{k}=\delta_{r^{\prime}}^{s^{\prime}}(7)$.

After substitution (5) - (7) in (4) we obtain the formula for representing the strain tensor components in the local coordinate system through the movements components in the basic [6]: 


$$
\varepsilon_{i j}=\frac{1}{2}\left(u_{k^{\prime}, i} z_{, j}^{k^{\prime}}+u_{k^{\prime}, j} z_{, i}^{k^{\prime}}\right)-u_{k^{\prime}} z_{, i}^{m^{\prime}} z_{, j}^{n^{\prime}} \Gamma_{m^{\prime} n^{\prime}}^{k^{\prime}} .
$$

Geometric Cauchy relationships in the Cartesian and the orthogonal cylindrical coordinate systems. The description of prismatic bodies and rotation bodies with variable geometrical and physical-mechanical parameters is most naturally carried out in the orthogonal cylindrical:

$$
g_{1^{\prime} 1^{\prime}}=g_{2^{\prime} 2^{\prime}}=1, g_{3^{\prime} 3^{\prime}}=\left(Z^{2^{\prime}}\right)^{2}, \Gamma_{3^{\prime} 3^{\prime}}^{2^{\prime}}=-Z^{2^{\prime}}, \Gamma_{3^{\prime} 2^{\prime}}^{3^{\prime}}=\Gamma_{2^{\prime} 3^{\prime}}^{3^{\prime}}=\frac{1}{Z^{2^{\prime}}}
$$

and the Cartesian coordinate systems:

$$
g_{1^{\prime} 1^{\prime}}=g_{2^{\prime} 2^{\prime}}=g_{3^{\prime} 3^{\prime}}=1, \Gamma_{l^{\prime} m^{\prime}}^{k^{\prime}}=0 .
$$

In this case, the metric tensor components in the local coordinate system are presented through the components in the basic by the formula:

$$
g_{i j}=z_{, i}^{1^{\prime}} 1_{, j}^{\prime}+z_{, i}^{2^{\prime}} z_{, j}^{2^{\prime}}+z_{, i}^{3^{\prime}} z_{, j}^{3^{\prime}} g_{3^{\prime} 3^{\prime}} \text {. }
$$

The relationship between movements and deformations (8) can be written as:

$$
\varepsilon_{i j}=\frac{1}{2}\left(u_{k^{\prime}, i} z_{, j}^{k^{\prime}}+u_{k^{\prime}, j} z_{, i}^{k^{\prime}}\right)-u_{2^{\prime}} z_{, i}^{3^{\prime}} z_{, j}^{3^{\prime}} \Gamma_{3^{\prime} 3^{\prime}}^{2^{\prime}}-u_{3^{\prime}} z_{, i}^{2^{\prime}} z_{, j}^{3^{\prime}} \Gamma_{2^{\prime} 3^{\prime}}^{3^{\prime}}-u_{3^{\prime}} z_{, i}^{3^{\prime}} z_{, j}^{2^{\prime}} \Gamma_{3^{\prime} 2^{\prime}}^{3^{\prime}} \text {. }
$$

Geometric Cauchy relationships for rotation bodies and rectilinear prismatic bodies. An important partial case of independent practical significance are objects with a canonical guide, for which the geometric equations (12) are greatly simplified. These are primarily heterogeneous circular rotation bodies and prismatic rectilinear bodies with a variable cross-sectional area.

Due to the convergence $x^{3}$ and $Z^{3^{\prime}}$, and their orthogonality to the crosssectional area in the cylindrical coordinate system $\left(0 \leq x^{3} \leq 2 \pi\right)$ :

$$
z_{, \alpha}^{3^{\prime}}=z_{, 3}^{\alpha^{\prime}}=0, \quad z_{, 3}^{3^{\prime}}=1
$$

in the Cartesian $\left(0 \leq x^{3} \leq 2\right)$ :

$$
z_{, \alpha}^{3^{\prime}}=z_{, 3}^{\alpha^{\prime}}=0, \quad z_{, 3}^{3^{\prime}}=a
$$

where $a$ is a half the body length.

Taking into account (13) and (14), the correlations (12) take the form in the orthogonal cylindrical coordinate system:

$$
\begin{gathered}
\varepsilon_{\alpha \beta}=\frac{1}{2}\left(z_{, \alpha}^{\gamma^{\prime}} u_{\gamma^{\prime}, \beta}+z_{, \beta}^{\gamma^{\prime}} u_{\gamma^{\prime}, \alpha}\right), \\
\varepsilon_{\alpha 3}=\frac{1}{2}\left(u_{3^{\prime}, \alpha}+z_{, \alpha}^{\gamma^{\prime}} u_{\gamma^{\prime}, 3}-\frac{2 z_{, \alpha}^{2^{\prime}} u_{3^{\prime}}}{Z^{2^{\prime}}}\right), \\
\varepsilon_{33}=u_{3^{\prime}, 3}+Z^{2^{\prime}} u_{2^{\prime}}
\end{gathered}
$$

in the Cartesian:

$$
\begin{gathered}
\varepsilon_{\alpha \beta}=\frac{1}{2}\left(z_{, \alpha}^{\gamma^{\prime}} u_{\gamma^{\prime}, \beta}+z_{, \beta}^{\gamma^{\prime}} u_{\gamma^{\prime}, \alpha}\right), \\
\varepsilon_{\alpha 3}=\frac{1}{2}\left(a u_{3^{\prime}, \alpha}+z_{, \alpha}^{\gamma^{\prime}} u_{\gamma^{\prime}, 3}\right),
\end{gathered}
$$




$$
\varepsilon_{33}=a u_{3^{\prime}, 3} .
$$

The stress tensor components in the local coordinate system are expressed through the strain tensor components based on the generalized Hooke's Law [6]:

$$
\sigma^{i j}=d^{i j k l} \varepsilon_{k l} \text {. }
$$

In isotropic body, the elastic constant tensor components $d^{i j k l}$ are related to the Lame coefficients $\lambda$ and $\mu$ ratios [23]:

$$
d^{i j k l}=\lambda g^{i j} g^{k l}+\mu\left(g^{j l} g^{i k}+g^{i l} g^{j k}\right),
$$

where $\lambda=\frac{E v}{(1-2 v)(1+v)}, \mu=\frac{E}{2(1+v)}, E=E\left(Z^{i^{\prime}}\right), v=v\left(Z^{i^{\prime}}\right)$ is the value of the elastic modulus and the Poisson's ratio at the body point under consideration.

Within the framework of the accepted dilatancy model for the soil in the boundary state, the deformation increment consists of two parts:

$$
d \varepsilon=d \varepsilon^{e}+d \varepsilon^{p} .
$$

The upper indexes $e$ and $p$ in the values notation indicate their elastic and plastic nature, respectively. The stress increment $d \sigma$ is associated with the elastic deformation increment by the ratio:

$$
d \sigma=C \cdot d \varepsilon^{e},
$$

where $C$ is the elastic constant tensor, the components of which are determined by the formula:

$$
C^{i j k l}=\frac{E}{1+v}\left[\frac{v}{1-v} q^{i j} q^{k l}+0.5\left(q^{i k} q^{j l}+q^{i l} q^{j k}\right)\right] .
$$

The parameters $E$ and $v$ denote, respectively, the medium elasticity modulus and the Poisson's ratio, and $q^{i j}$ are the metric tensor components.

The plastic deformation increment $d \varepsilon^{p}$ is determined based on the unassociated law of plastic flow:

$$
d \varepsilon^{p}=d \lambda \frac{\partial F}{\partial \sigma}
$$

where $F$ is the plastic potential function, $d \lambda$ is the small scalar factor that determines the absolute value $d \varepsilon^{p}$.

With it:

$$
F \neq f,
$$

where $f$ is the function that determines the plasticity condition $(f=0)$.

The modified Mises-Schleicher-Botkin condition is used as the boundary state criterion:

$$
\left\{\begin{array}{lll}
f=T+\sigma_{m} \operatorname{tg} \psi-\tau_{s} & \text { if } & \sigma_{m} \leq p_{o}, \\
f=T+p_{o} \operatorname{tg} \psi-\tau_{s} & \text { if } & \sigma_{m}>p_{o},
\end{array}\right.
$$

$\sigma_{m}$ is the average (hydrostatic) pressure: 


$$
\sigma_{m}=\frac{1}{3} \sigma^{i j} q_{i j},
$$

$T$ is the intensity of tangent stresses (the second invariant of the stress deviator):

$$
T=\sqrt{\frac{1}{2} S^{i j} S_{i j}}, S_{i j}=\sigma_{i j}-\frac{1}{3} \sigma_{m} q_{i j},
$$

$\psi$ - the friction angle on the octahedral site, $H_{R}=\frac{\tau_{s}}{\operatorname{tg} \psi}$ is the ultimate resistance to uniform tension, $p_{o}$ is the soil medium parameter. The condition (24) in the space of principal stresses corresponds to the combined boundary surface, which is a combination of a cone and a cylinder (Fig. 1).

The need to accept the condition (24) is due to the fact that with a large all-round compression, soils behave like solid bodies, in which it is not possible to achieve loosening even with significant shearings, i.e. there is no dilatancy, and in addition, the ultimate shear load is no longer dependent on the compression level. This corresponds to the acceptance of the conditions for the

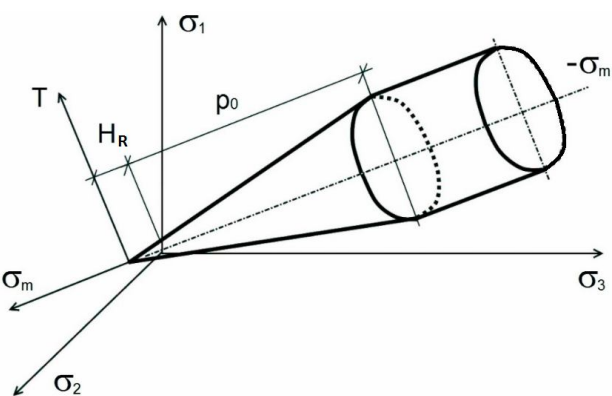

Fig. 1. Loading surface.

General view in space of principal stresses medium plastic incompressibility and the independence of the limiting shear load from the uniform pressure level - the cylindrical part of the modified condition (24). The value of the parameter $p_{o}$ of the conical part transition (24) to the cylindrical one was taken equal to $p_{o}=-2,0 \mathrm{MPa}$ in accordance with the experimental data of Sidorov and Sipidin [26].

The modified criterion (24) has another distinctive feature. The MisesSchleicher-Botkin condition in it is consistent with the Coulomb-Mohr condition in such a way that for all kinds of stress states the discrepancy (in the limiting value $T$ ) is minimal. In addition, the expressions $\tau_{s}$ and $\operatorname{tg} \psi$ were obtained as functions of the norming parameters $c$ (adhesion) and $\varphi$ (angle of internal friction).

$$
\tau_{s}=\frac{6 \sqrt{3} C \cos \varphi}{9-\sin ^{2} \varphi}, \operatorname{tg} \psi=\frac{6 \sqrt{3} \sin \varphi}{9-\sin ^{2} \varphi} .
$$

The procedure for obtaining (27) is described in detail in the work [7].

It can be shown that upon the direct differentiation of the plastic potential function, the expression $\frac{d F}{d \sigma^{i j}}$ is similar to that obtained by A.K. Bugrov [9]: 


$$
F=T+\sigma_{m} \lambda(x)+\text { const } .
$$

It should be noted that the need to accept the potential in the form (28) was pointed out by A.S. Stroganov [30], but all his constructions were made within the framework of the deformation theory of soil plasticity. A.S. Stroganov emphasized [30] that the actual value of the dilatancy coefficient $\lambda$ is always less than the value $\operatorname{tg} \psi$, i.e. the condition of association $\lambda=\operatorname{tg} \psi$ is not met. A similar form of the potential surface was proposed in the works [32].

V.N. Nikolaevskiy [15] showed that the nature of the plastic potential function corresponding to the dilatancy model depends on the sign of the dilatancy coefficient $\lambda$ and is represented by the expression:

$$
F=T^{2}-\lambda \operatorname{tg} \psi\left(\sigma_{m}+H_{R}\right)^{2} .
$$

For $\lambda<0$, the surface corresponding to the function $F$ has the form of an ellipse arc, for $\lambda=0$, a straight line segment, and for $\lambda>0$, a hyperbola arc.

In the closing correlations $\lambda=\lambda(x)$ in the works of V.N. Nikolaevskiy, the volumetric plastic deformation [16] and the density [14] are used as the hardening parameter. In the work [14], the following formula is proposed to determine the dilatancy coefficient:

$$
\lambda=-\sqrt{1-\left(\frac{\rho}{\rho^{\mathrm{cr}}}\right)^{2}} \text { for } \rho<\rho^{\mathrm{cr}}, \lambda=\sqrt{1-\left(\frac{\rho^{\mathrm{cr}}}{\rho}\right)^{2}} \text { for } \rho>\rho^{\mathrm{cr}},
$$

where $\rho$ is the current density, $\rho^{\text {cr }}$ is the critical density at a given hydrostatic pressure $\rho^{\text {cr }}=\rho^{\text {cr }}\left(\sigma_{m}\right)$. The angle of internal friction is also variable.

$$
\varphi=\varphi_{0}+\arcsin \lambda
$$

where $\varphi_{0}$ is the angle of internal friction of the soil when it reaches the critical density.

The variable value of the angle of internal friction $\varphi$ determines the nature of the dilatancy elastic-plastic model hardening, and the loading surfaces represent a family of straight lines on the plane (Fig. 2).

In the formula (30), the density $\rho$ is taken as the hardening parameter. In this case, the following conditions are satisfied, which follow directly from the initial preconditions of the model:

$$
\left\{\begin{array}{l}
\lambda>0 \text { if } \rho>\rho^{\mathrm{cr}} \\
\lambda<0 \text { if } \rho<\rho^{\mathrm{cr}} ; \\
\lambda=0 \text { if } \rho=\rho^{\mathrm{cr}} .
\end{array}\right.
$$

The expressions for the angle (coefficient) of internal friction (31) contain two components, and when the soil reaches the critical density (porosity), one of the components becomes equal to zero. The need to separate the strength of sandy soil was noted as early as 1950 by A. Skempton and A. Bishop [27], 
who proposed to consider separately the strength due to friction and due to dilatancy. In 1958 B. Hansen introduced the concept of dilatancy angle. The variable nature of the angle of internal friction of the soil was emphasized by K. Roscoe [5, 2] and A. Bishop [5]. The strength division into two components in the expression of the yield

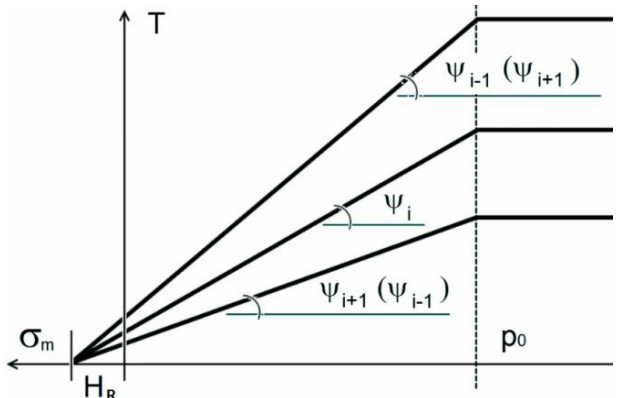

Fig. 2. Loading surfaces. Meridional sections function is also used by V.N. Shirokov [25].

Of the two components of the angle of internal friction, one (namely, the dilatancy angle), as indicated, is a variable value tending to zero at the critical density, and the other component is a constant value over a wide pressure range and does not depend on the initial density.

In describing the concept of critical density (porosity), it was pointed out the need to take into account its dependence on the hydrostatic pressure level. At low pressures, a significant change in the critical density does not occur, however, when it reaches $\sigma_{m}$ about 1.0-2.0 $\mathrm{MPa}$, it can significantly increase, and at $\sigma_{m}>2.0 \mathrm{MPa}$, the dilatancy loosening is practically impossible to achieve. To describe this phenomenon, the dependence of the critical density on the hydrostatic pressure was introduced in [5] in the form:

$$
\begin{cases}\rho_{\mathrm{cr}}=\rho_{\mathrm{cr}}^{o}, & \text { if } \sigma_{m}>0, \\ \rho_{\mathrm{cr}}=-\frac{2 \rho_{\mathrm{cr}}^{m}-\rho_{\mathrm{cr}}^{o}}{P_{o}^{3}} \sigma_{m}^{3}+\frac{3\left(\rho_{\mathrm{cr}}^{m}-\rho_{\mathrm{cr}}^{o}\right)}{P_{o}^{2}}+\rho_{\mathrm{cr}}^{o}, & \text { if } \rho_{o} \leq \sigma_{m} \leq 0, \\ \rho_{\mathrm{cr}}=\rho_{\mathrm{cr}}^{m}, & \text { if } \sigma_{m}<\rho_{o},\end{cases}
$$

where $\rho_{\mathrm{cr}}^{o}$ is the critical density in the absence of hydrostatic pressure, $\rho_{\mathrm{cr}}^{m}$ is the maximum density of the given soil, the soil medium parameter, taken $P_{o}=-2,0 \mathrm{MPa}$. The dependence diagram (33) is shown on Fig. 3.

One of the most common issues in modeling the "structure-soil massif" system is the choice of the calculation area boundaries. The issue of choosing the model lower boundary is especially acute if the object of study is subsidence. In this case, the calculation model sizes should be chosen so that the influence of boundary conditions on the forces

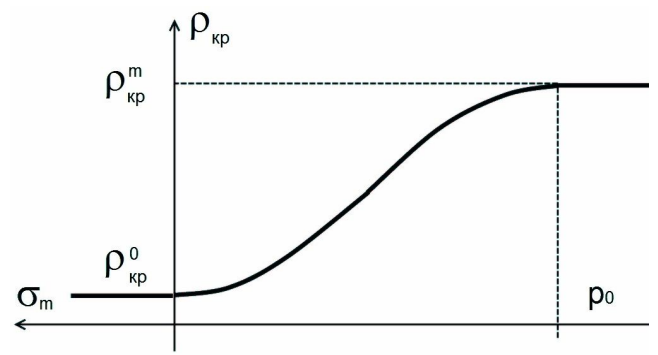

Fig. 3. Diagram of dependence of critical density on hydrostatic pressure 
distribution was minimal [18]. This approach is implemented in the works of Berezhnyi D.V., Sagdatullin M.K., Sultanov L.U., Petrov D.N., Demenkov P.O., Potiomkin D.O. [3, 18]. On the other hand, while reducing the impact on the forces distribution, this leads to an unjustified increase in subsidence deformations. In this case, it is recommended to limit the calculation scheme to the compressible zone depth $[17,10]$.

However, often, due to the peculiarities of the studied objects, it is impossible to use the recommendation to limit the calculation scheme to the compressible zone depth. Therefore, the issue of developing such approaches to modeling the "structure-soil massif" system is relevant, for which the subsidence values in the calculation were identical regardless of the selected lower limit of the calculation model. In order to overcome these problems in the works $[28,29]$ the detailed description of the accepted correlations, as well as the step-by-step algorithm for the correction of the elasticity mole of the reinforced elastic-plastic medium are presented:

$$
E_{\text {inc }}=\frac{E^{r e f} m}{\frac{c \cdot \operatorname{ctg} \varphi}{\gamma \cdot K_{0}}+z_{r e f}} .
$$

The above ratios make it possible to model the stress-strain state of the soil medium, to determine the pressure distribution in the soil under its own weight and various external influences, taking into account the medium heterogeneity, changes in the relief and physical and mechanical characteristics in the deformation process.

2. Finite element method model. Known analytical methods for determining the structure deformation parameters are usually based on idealized schemes, which significantly narrows the scope of their use. There is a large layer of experimental methods, which are traditionally considered the most reliable basis for obtaining real data. But in practice, we often face more complex geometric shapes and mechanical processes. In this case, numerical methods are brought to the forefront, the most common of which is the finite element method (FEM). FEM has become very widely used in world engineering practice. Almost all known computational complexes rest on its scientific basis. However, there are a number of issues within the task scope, the effectiveness of solution of which requires further development of existing approaches. Structure design standards require considering joint work of structures and bases. It is known that soils show significant nonlinearity, the nature of which varies depending on the load type: deviator or isotropic. The dependence of the deformation characteristics on the stress state in the base, the process development over time, etc. adds to the difficulties.

The solution of the problems of elastic-plastic deformation of spatial bodies is based on the use of the semi-analytic finite element method (SAFEM) and the moment scheme of finite element (MSFE) [2, 19]. The underlying hypotheses allow us to describe arbitrary circular and prismatic geometric configurations with a variable cross-sectional area and heterogeneous material features under arbitrary boundary conditions (Fig. 4). 

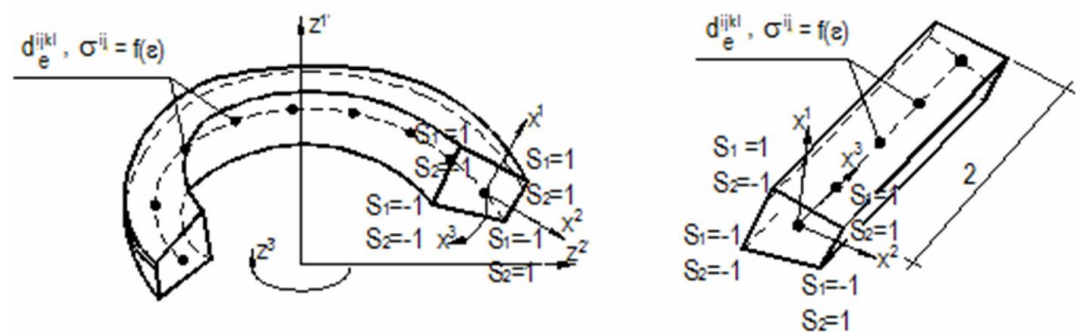

Fig. 4. Closed circular and prismatic finite elements of SAFEM

Based on the basic circular and prismatic finite elements of SAFEM, a new special finite element (FE) has been developed for modeling a nonlinear elastic-plastic soil base. The feature of the accepted FE is the stress tensor correction obtained at the next stage under the load parameter under the assumption of the soil linear operation on the deformation increment. For soil that is in the borderline state, the stress differential has the form:

$$
d \sigma^{i j}=C^{i j k l} d \varepsilon_{k l}^{e}=C^{i j k l}\left(d \varepsilon_{k l}-d \varepsilon_{k l}^{p}\right)=d \sigma_{e}^{i j}-d \lambda C^{i j k l} \frac{\partial F}{\partial \sigma^{k l}} .
$$

where $C^{i j k l}$ is the deformation constant tensor; $d \varepsilon_{k l}, d \varepsilon_{k l}^{e}, d \varepsilon_{k l}^{p}$ are the differentials of complete, elastic and plastic deformations, respectively; $d \sigma_{e}^{i j}$ is the stress increment provided that $d \varepsilon_{k l}^{p}=0$.

Within one step it is considered tt the material does not strengthen and for it the condition of a borderline state is fulfilled:

$$
\frac{\partial f}{\partial \sigma^{i j}} d \sigma^{i j}=0 \text {. }
$$

Solving together (35) and (36) we get the expression for $d \lambda$. :

$$
d \lambda=\frac{\frac{\partial f}{\partial \sigma^{m n}} C^{m n l k} d \varepsilon_{k l}}{\frac{\partial f}{\partial \sigma^{u v}} C^{u v s t} \frac{\partial F}{\partial \sigma^{s t}}}
$$

and substituting this in (35) we get:

$$
d \sigma^{i j}=d \sigma_{e}^{i j}-C^{i j g r} \frac{\partial F}{\partial \sigma^{g r}} \frac{\frac{\partial f}{\partial \sigma^{m n}} C^{m n l k} d \varepsilon_{k l}}{\frac{\partial f}{\partial \sigma^{u v}} C^{u v s t} \frac{\partial F}{\partial \sigma^{s t}}} .
$$

Dilatancy ratios are analogous to the use of the plastic potential function in the form of:

$$
F=T+\sigma_{m} \Lambda+\text { const }
$$

After differentiation we get: 


$$
\frac{\partial F}{\partial \sigma^{i j}}=\frac{S_{i j}}{2 T}+\frac{\Lambda \sigma_{i j u}}{3 \sigma_{m}},
$$

where $S_{i j}$ and $\sigma_{i j u}$ are the components of the deviator and layer part of the stress tensor, respectively.

Expression $\frac{\partial f}{\partial \sigma^{i j}}$, where $f$ is the yield function according to (24) is written similarly:

$$
\frac{\partial f}{\partial \sigma^{i j}}=\frac{S_{i j}}{2 T}+\frac{\operatorname{tg} \psi \sigma_{i j u}}{3 \sigma_{m}} .
$$

Taking into account the expressions (40) and (41) for (38) we get:

$$
d \sigma^{i j}=d \sigma_{e}^{i j}-\left(\frac{\mathrm{G}}{T} S^{i j}+\frac{\mathrm{K} \Lambda}{\sigma_{m}} \sigma_{i j u}\right) d L,
$$

where $K$ and $G$ are the volumetric and shear elasticity modulus, respectively, related to the traditional parameters $\mathrm{E}$ and $v$ ratios:

$$
K=\frac{E}{3(1-2 v)} ; G=\frac{E}{2(1+v)},
$$

$d L$ is the small scalar multiplier:

$$
d L=\frac{1}{A}\left(\frac{G}{T} S^{k l}+\frac{K \operatorname{tg} \psi}{\sigma_{m}} \sigma_{u}^{k l}\right) d \varepsilon_{k l}
$$

$A$ is the constant, which is determined:

$$
A=G+K \Lambda \operatorname{tg} \psi .
$$

The integration of the expression (42) allows determining the stress tensor component increment $\Delta \sigma^{i j}$ at this step. The following method is more efficient for calculating the equations discrepancies.

In the transition in (42) from the differentials to increments in the assumption that $\Delta \sigma^{i j}$ and $\Delta \sigma_{e}^{i j}$ are determined from the same stress state $\sigma^{i j}$, determined in the previous step by the load parameter then:

$$
\begin{gathered}
S^{i j}=\left(1-\frac{\mathrm{G} \Delta L}{T+\mathrm{G} \Delta L}\right) S_{e}^{i j}, \\
\sigma_{u}^{i j}=\left(1-\frac{\mathrm{K} \Lambda \Delta L}{\sigma_{m}+\mathrm{K} \Lambda \Delta L}\right) \sigma_{u e}^{i j} .
\end{gathered}
$$

Therefore, it is seen that for the soil which is in the boundary state, the deviator $S^{i j}$ and the layer $\sigma_{u}^{i j}$ components of the stress tensor $\sigma^{i j}$ are proportional to the respective components $S_{e}^{i j}$ and $\sigma_{m e}^{i j}$ of the stress tensor $\sigma_{e}^{i j}$, determined in the assumption that on the next deformation increment $\Delta \varepsilon_{k l}$ the soil operates linearly: 


$$
S^{i j}=q_{1} S_{e}^{i j}, \quad \sigma_{u}^{i j}=q_{2} \sigma_{u e}^{i j}
$$

By substituting (48) in (46) and (47) we get:

$$
\begin{aligned}
& q_{1}=\frac{1}{T_{e}} \frac{-\operatorname{tg} \psi\left(\sigma_{m e}-T_{e} \frac{K \Lambda}{G}\right)+\tau_{s}}{-\operatorname{tg} \psi \frac{K \Lambda}{G}+1}, \\
& q_{2}=\frac{1}{\sigma_{m e}} \frac{\left(\sigma_{m e}-T_{e} \frac{K \Lambda}{G}\right)+\tau_{s} \frac{K \Lambda}{G}}{\operatorname{tg} \psi \frac{K \Lambda}{G}+1} .
\end{aligned}
$$

The correlations for $q_{1}$ and $q_{2}$ can also be obtained from the geometric constructions by considering the meridional cross section of the plasticity surface at a given step of the load parameter in the axes $\left(T, \sigma_{m}\right)$ in Fig. 5. The correction process consists in drawing a straight line at the angle $\alpha$ to the axis $\sigma_{m}$ through the point $A$ to the intersection with the straight section of the plasticity surface. The cross-point $C$ $\left(T, \sigma_{m}\right)$ will be the desired stress state. It can be seen from the constructions that $\operatorname{tg} \alpha=\frac{A B}{B D}$, where $A B$ and $B D$ are the invariants of the

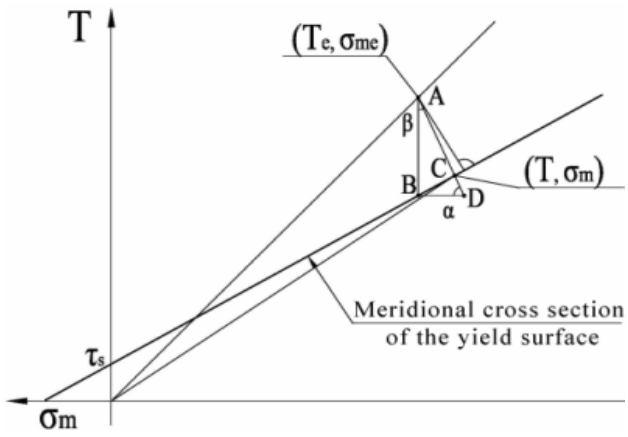

Fig. 5. Geometric interpretation of ratios of the stress tensor correction

fictitious stress tensor determined in the assumed elastic work of the soil outside the plasticity surface.

Therefore:

$$
\operatorname{tg} \alpha=\frac{A B}{B D}=\frac{G d \gamma^{p}}{K d \varepsilon_{m}^{p}}=\frac{G d \gamma^{p}}{K \Lambda d \varepsilon_{m}^{p}}=\frac{G}{K \Lambda} .
$$

The equation of the straight line $\mathrm{AC}$ takes the form:

$$
T-T_{e}=\frac{G}{K \Lambda}\left(\sigma_{m}-\sigma_{m e}\right) .
$$

To find $T$ and $\sigma_{m}$ it is necessary to solve the system of two equations:

$$
\left\{\begin{array}{l}
T=\frac{G}{K \Lambda}\left(\sigma_{m}-\sigma_{m e}\right)+T_{e} \\
T=-\sigma_{m} \operatorname{tg} \psi+\tau_{s}
\end{array}\right.
$$


By denoting $T=q_{1} T_{e}$ and $\sigma_{m}=q_{2} \sigma_{m e}$ from the system of equations we find the values of the coefficients $q_{1}$ and $q_{2}$, which are analogous to (49) and (50), which proves the correctness of these coefficients definition.

Conclusions. Therefore, on the basis of modern numerical implementations of the finite element method, the theoretical foundations of the analysis of nonlinear deformation processes of machines and structures in their contact interaction with the elastic-plastic medium within the threedimensional spatial problem taking into account the previous stress state and load history are presented. The methodology of construction of computational models of joint deformation and mutual influence of rigid structures and essentially plastic external medium is developed, new special heterogeneous finite elements of SAFEM of general form with variable geometrical and physical-mechanical parameters and arbitrary boundary conditions for approximation of arrays of hardly connected reinforced soils are developed.

\section{REFERENCES}

1. Alexanderov A.S. Modification of the criterion of Kulon-Mora for raschet constructive roads on the resistance of the sdvyh. Part 1. Enter the third parameter of the motherhood / A.S. Alexanderov, G.V. Dolgikh // Mezhdunarodnyi nauchno-issledovatelskii zhurnal. - 2016. - №. 6$2(48)$.

2. Bazhenov V.A. Formulation and calculation ratios of the problem of destruction mechanics for spatial bodies under the action of dynamic loads within the semi-analytical method of finite elements / V.A. Bazhenov, I.I Солодей, М.О Вабіщевич, О.О Чепурна // Opir materialiv i teoriia sporud. - 2017. - №. 99. - P. 58-70.

3. Berezhnoy D.V. Choosing a soil model for numerical simulation of the influence of deep excavation on the existing building. / D.V. Berezhnoy, M.K. Sagdatullin, L.U. Sultanov // Bulletin of Kazan Technological University. - 2013. - № 9. - P. 250-255.

4. Bhutto A.H. Mohr-Coulomb and hardening soil model comparison of the settlement of an embankment dam / A.H. Bhutto et al. //Engineering, Technology \& Applied Science Research. - 2019. - T. 9. - №. 5. - P. 4654-4658.

5. Bishop A.U. Strength parameters when undisturbed and crumpled soil samples shift / A.U. Bishop // Opredeliaiushchie zakony mehaniki gruntov. - M.: Mir, 1975. P. 7-75.

6. Blokh V.I. Theory of resilience / V.I. Blokh - Harkov: Izd-vo Hark. un-ta.- 1964. -483 p.

7. Boiko I.P. The method of numerical modeling of the development of limit-state zones in the ground of the bases under the ICE / I.P. Boiko, A.E. Delnik, A.S. Saharov-K.: Inzh.-stroit. int., $1983 .-46 \mathrm{p}$.

8. Bower T.A., Jefferson A.D., Cleall P.J. A reformulated hardening soil model / T.A. Bower, A.D. Jefferson, P.J. Cleall //Proceedings of the Institution of Civil Engineers-Engineering and Computational Mechanics. - 2020. - T. 173. - №. 1. - P. 11-29.

9. Bugrov A.K. On solving the mixed problem of the theory of elasticity and the theory of plasticity of primes / A.K. Bugrov // Osnovaniia, fundamenty i mehanika gruntov. - 1974. №36. - P. 20-23.

10. Horodetskii A.S. Kompiuternye modeli konstruktsii (Computer models of constructions) / A. S. Horodetskii, I. D. Evzerov. - Kiev: Fakt, 2005. -344 p.

11. Kudasheva M.I. Comparison of the Mor-Coulomb model and the hardening ground model in the Plaxis software complex / M.I. Kudasheva, C.V. Kaloshina // Stroitelstvo i arhitektura. Opyt i sovremennye tekhnologii. - 2017. - Resource Access Mode: http://sbornikstf.pstu.ru/council/?n=9

12. Melnikov R.V. Calibrating the Hardening Soil parameters based on laboratory tests in the program Soiltest / R.V. Melnikov, R.K. Sagitova. // Akademicheskii vestneyk UralNIIproekt RAASN. - 2016. - № 3. - P. 79-83. 
13. Mirnyi A.Iu. Areas of use of modern mechanical models of soils / A.Iu. Mirnyi, A.Z. TerMartirosian. // Geotekhnika. - 2017. - № 1. - P. 20-26.

14. Nicolaevskii V.N. Determining equations of plastic deformation of the loose environment / V.N. Nicolaevskii // PMM. - 1971. - т. 35, № 6. - P. 1070-1082.

15. Nicolaevskii V.N. Dilatansia and the laws of irreversible deformation of soils / V.N. Nicolaevskii // Osnovaniia, fundamenty i mehanika gruntov. - 1979. - № 5. - P. 29-32.

16. Nicolaevskii V.N. Dynamics of elastic-plastic dilating environments / V.N. Nicolaevskii, N.M. Syrnikov, G.M. Shchefter // V kn.: Uspehi mehaniki deformiruemykh sred. - M.: Nauka, 1975. - P. 397-413.

17. Perelmuter A.V. Raschetnye modeli sooruzhenij i vozmozhnost ikh analiza (Design models of structures and the possibility of their analysis) / A.V. Perelmuter, V.I. Slivker. - Moscow: SKAD SOFT, $2011.736 \mathrm{p}$.

18. Petrov, D.N., Demenkov, P.A., Potemkin, D.A. Numerical modeling of the stress state in the lining of columnar stations without side platforms. / D.N. Petrov, P.A Demenkov., D.A. Potemkin // Notes of the Mining Institute. - 2010. - 185. - P. 166-170.

19. Piskunov S. O..Features of the use of the torque scheme of finite elements (ISSE) in linear calculations of shells and plates. / S.O. Piskunov, I.I. Solodei, Iu.V.Maksimiuk, \& A.D. Solodenko // Opir materialiv ta teoriia sporud, (91), P. 62-78.

20. Pramthawee $P$. Integration of creep into a modified hardening soil model for time-dependent analysis of a high rockfill dam / P.Pramthawee, P.Jongpradist, R.Sukkarak // Computers and Geotechnics. - 2017. - T. 91. - P. 104-116.

21. Riabkov S.V. Experience of the Plaxis 3D software complex by the tunnel construction design department / C.V. Riabkov, H.A. Solovev. // Metro i tonneli. - 2016. - №9. - P. 53-55.

22. Rosko K. The value of deformations in soil mechanics / K. Rosko // V kn.: Mehanika. - M.: Mir, 1971. - № 3 (127). - P. 91-145.

23. Saharov A.S. End-of-life method in solid mechanics / A.S. Saharov, V.N. Kislookii, V.V. Kirichevskii i dr. - Kiev: Vishcha shkola, 1982.- 479p.

24. Schweiger H.F. Examples of successful numerical modelling of complex geotechnical problems / H.F. Schweiger et al. // Innovative Infrastructure Solutions. - 2019. - T. 4. - №. 1. - P. 2.

25. Shirokov V. N. Model of sandy soil / V.N. Shirokov // V kn.: Sovremennye problemy nelineinoi mehaniki gruntov, Cheliabinsk, ChPI. - 1985. - P. 27-28.

26. Sidorov N.I., Spidin V.P. Modern methods of determining the characteristics of mechanical properties of soils / N.I. Sidorov, V.P. Spidin. - L.: Stroiizdat, 1972. - 136 p.

27. Skocsylas K. Analiza statecznosci skaroy nawodnionej / K. Skocsylas, E. Stilger-Szyd Lo // Prace Naukowe Insc Geotech. Politech. Wroclawskij. - 1987. - K 52. - P. 317-322.

28. Solodei I. Implementation of the linear elastic structure half-space in the Plaxis in the study of settlements / I. Solodei I., Gh. Zatyliuk // Proceedings of Odessa Polytechnic University. 2019. - № 1 (57). - P. 22-28.

29. Solodei I. Mohr-coulomb model with corrected parameters in the study of base settlements / I. Solodei, Gh. Zatyliuk // The Austrian Journal of Technical and Natural Sciences, Premier Publishing s.r.o. Vienna. 2020.- 9-10 - P.36-39.

30. Stroganov A.S. Analysis of flat plastic deformation of the ground / A.S. Stroganov // Inzhenernyi zhernal. - 1965. - tom 5, vyp. 4. - P. 734-742.

31. Xiang $X$. Numerical implementation of a modified Mohr-Coulomb model and its application in slope stability analysis / X. Xiang, D. Zi-Hang //Journal of Modern Transportation. -2017. - T. 25. - №. 1. - P. 40-51.

32. Zienkiewicz O.C. Non-linear seismic response and liquefaction / O.C. Zienkiewicz, C.T. Chang, E. Hinton // Intern. J. Numer. and Anal. Meth. Geomech. - 1978. - Vol. 2. - N4. - P. 381-404. 


\section{Солодей I.I., Петренко Е.Ю., Затилюк Г.А.}

\section{НЕЛІНІЙНА ЗАДАЧА ДЕФОРМУВАННЯ КОНСТРУКЦІЙ ПРИ ВЗАЄМОДІЇ ІЗ ПРУЖНОПЛАСТИЧНИМ СЕРЕДОВИЩЕМ}

У статті на базі сучасних чисельних реалізацій метода скінченних елементів представлені теоретичні основи аналізу процесів деформування конструкцій машин і споруд при їх контактній взаємодії із пружнопластичним нелінійним грунтовим середовищем в рамках тривимірної просторової задачі з урахуванням попереднього напруженого стану та історії навантаження. Створена методика побудови розрахункових моделей сумісного деформування і взаємного впливу жорстких конструкцій і суттєво пластичного зовнішнього середовища, розроблені нові спеціальні неоднорідні скінченні елементи НМСЕ загального вигляду із змінними геометричними і фізико-механічними параметрами та довільними граничними умовами для апроксимації масивів малозв'язних зміцнюваних грунтів.

Ключові слова: пружнопластичне середовище, модель зміцнюваних грунтів, напіваналітичний метод скінченних елементів, моментна схема скінченного елемента.

\section{Solodei I.I., Petrenko E.Yu., Zatyliuk Gh.A. \\ NONLINEAR PROBLEM OF STRUCTURAL DEFORMATION IN INTERACTION WITH ELASTOPLASTIC MEDIUM}

The use of numerical methods in the calculation of machines and structures, taking into account their interaction with the elastic-plastic medium is largely determined by the complexity or even impossibility of analytical calculation due to the complexity of structural schemes, heterogeneity of material features, uneven soil layers, implementation of step-by-step work execution technologies and so on.

Compatible calculations of structures and nonlinear basis, which are described by modern mechanical and soil models in one problem is a significant technical problem. And neither the existing "problem-oriented" software packages, nor the "universal" ones - do not fully contain such models.

The tasks solution is possible only within the framework of numerical methods, the most common of which is the finite element method (FEM). The construction of the calculated finite element model raises many complex questions that require additional detailed study. In addition, the compliance with the state building norms and regulations is an important factor for further practical use.

The combination of the latest achievements in the field of structural mechanics and soil mechanics is a promising direction for the development of effective approaches for building discrete models of spatial systems "structure-nonlinear base" for solving applied problems.

On the basis of modern numerical implementations of the finite element method the article presents the theoretical foundations of the analysis of deformation processes of machines and structures in their contact interaction with the elastic-plastic nonlinear soil medium within the three-dimensional spatial problem taking into account the previous stress state and load history. The methodology of construction of computational models of joint deformation and mutual influence of rigid structures and essentially plastic external medium is developed, new special heterogeneous finite elements of SAFEM of general form with variable geometrical and physical-mechanical parameters and arbitrary boundary conditions for approximation of arrays of hardly connected reinforced soils are developed.

Keywords: elastic-plastic medium, reinforced soils model, semi-analytical finite element method, moment scheme of finite element.

\section{Солодей И.И., Петренко Э.Ю., Затылюк Г.А. \\ НЕЛИНЕЙНАЯ ЗАДАЧА ДЕФОРМИРОВАНИЯ КОНСТРУКЦИЙ ПРИ ВЗАИМОДЕЙСТВИИ С УПРУГОПЛАСТИЧЕСКОЙ СРЕДОЙ}

В статье на базе современных численных реализаций метода конечных элементов представлены теоретические основы анализа процессов деформирования конструкций машин и сооружений при их контактном взаимодействии с упругопластической нелинейной грунтовой средой в рамках трехмерной пространственной задачи с учетом предыдущего напряженного состояния и истории нагрузки. Создана методика построения расчетных моделей совместного деформирования и взаимного влияния жестких конструкций и существенно пластической внешней среды, разработаны новые специальные неоднородные конечные элементы HМСE общего вида с переменными геометрическими и физикомеханическими параметрами и произвольными граничными условиями для аппроксимации массивов малосвязных упрочняющихся грунтов.

Ключевые слова: упругопластическая среда, модель упрочняющихся грунтов, полуаналитический метод конечных элементов, моментная схема конечного элемента. 


\section{УДК 539.3}

Солодей I.I., Петренко Е.Ю., Затилюк Г.А. Нелінійна задача деформування конструкцій при взаємодії із пружнопластичним середовищем // Опір матеріалів і теорія споруд: наук.-тех. збірн. - К.: КНУБА, 2020. - Вип. 105. - С. 48-63.

Розглянуто метод розв'язання задач деформування конструкиій машин і споруд при їх контактній взаємодії із пружнопластичним нелінійним грунтовим середовищем.

Іл. 5. Бібліогр. 32 назв.

\section{UDC 539.3}

Solodei I.I., Petrenko E.Yu., Zatyliuk Gh.A. Nonlinear problem of structural deformation in interaction with elastoplastic medium // Strength of Materials and Theory of Structures: Scientific-and-technical collected articles. - K.: KNUBA, 2020. - Issue 105. - P. 48-63.

The method of solving the nonlinear deformation problems of structures during their contact interaction with the elastic-plastic medium is considered.

Fig. 5. Ref. 32.

\section{УДК 539.3}

Солодей И.И., Петренко Э.Ю., Затылюк Г.А. Нелинейная задача деформирования конструкций при взаимодействии с упругопластической средой // Сопротивление материалов и теория сооружений. - 2020. - Вып. 105. - С. 48-63.

Рассмотрен метод решения задач деформирования конструкиий машин и сооружений при их контактном взамодействии с упругопластической нелинейной грунтовой средой. Ил. 5. Библиогр. 32 назв.

Автор: доктор технічних наук, професор, професор кафедри будівельної механіки СОЛОДЕЙ Іван Іванович

Адреса: 03037 Украӥна, м. Київ, Повітрофлотський проспект 31, Київський національний університет будівництва і архітектури

Робочий тел.: +38 (044) 241-55-55

Мобільний тел.: +38 (050)357-44-90

E-mail: solodei.ii@knuba.edu.ua

ORCID ID: http://orcid.org/0000-0001-7638-3085

Автор: кандидат технічних наук, доцент, дочент кафедри геотехніки ПЕТРЕНКО Едуард Юрійович

Адреса: 03037 Украӥна, м. Київ, Повітрофлотський проспект 31, Київський національний університет будівництва і архітектури

Email: petrenko.ey@knuba.edu.ua

ORCID ID: http://orcid.org/0000-0002-9792-4757

Автор: аспірант, асистент кафедри будівельної механіки ЗАТИЛЮК Герман Анатолійович Адреса: 03037 Україна, м. Київ, Повітрофлотський проспект 31, Київський національний університет будівничтва і архітектури

Мобільний тел.: +38 (099) 11-00-564

Email: zatyliuk.ha@knuba.edu.ua

ORCID ID: http://orcid.org/0000-0003-0392-2214 